\title{
Development of a new method for identification and quantification in cerebrospinal fluid of malignant cells from breast carcinoma leptomeningeal metastasis
}

\author{
Emilie Le Rhun ${ }^{1 *}$, Frédéric Massin ${ }^{2}$, Qian Tu ${ }^{3}$, Jacques Bonneterre ${ }^{4}$, Marcelo De Carvalho Bittencourt ${ }^{5}$
} and Gilbert C Faure ${ }^{6}$

\begin{abstract}
Background: The diagnosis of leptomeningeal metastasis (LM) in patients with solid tumors remains difficult. The usual diagnostic methods of cytomorphological assessment of cerebro-spinal fluid (CSF) and gadolinium enhanced MRI of the entire neuraxis lack both specificity and sensitivity. The Veridex CellSearch ${ }^{\circledR}$ technology has been designed for the detection of circulating tumor cells (CTC) in blood from cancer patients and validated for the follow-up and prognosis of breast, prostate, colorectal, and lung cancer. Our aim was to adapt this technology for the detection and the enumeration of tumor cells in the CSF of breast cancer patients presenting with LM.

Methods: On the occasion of a randomized phase III study evaluating the role of the intrathecal treatment in LM from breast cancer (DEPOSEIN, EudraCT N: 2010-023134-23), the CellSearch ${ }^{\circledR}$ technology was adapted to direct enrichment, enumeration and visualization of tumor cells in $5 \mathrm{~mL}$ CSF samples, collected on CellSave ${ }^{\circledR}$ Preservative Tubes and analyzed within 3 days after CSF sampling.
\end{abstract}

Results: Sixteen CSF of 8 patients with primary breast cancer presenting with LM were studied. EpCAM+/cytokeratin + cells with typical morphology could be observed and enumerated sequentially with reproducible results in low or elevated numbers in 8 patients.

Conclusion: This methodology, established on a limited volume of sample and allowing delayed processing, could prove of great interest in the diagnosis and follow-up of cancer patients with LM, especially to appreciate the efficacy of chemotherapy.

Keywords: Leptomeningeal metastasis, Neoplastic meningitis, Meningeal carcinomatosis, CellSearch ${ }^{\circledR}$ technology, Immunomagnetic enrichment, CSF cytology

\section{Background}

Solid tumors, mostly breast cancer, lung cancer and melanoma, can result in leptomeningeal metastasis (LM) in 5 to $19 \%$ of patients [1]. The incidence of central nervous system (CNS) metastasis and LM may increase in the coming years because of a prolonged control of extra-cerebral disease and because of the use of antineoplastic agents with a poor diffusion into the CNS [2].

\footnotetext{
* Correspondence: E-lerhun@o-lambret.fr

${ }^{1}$ Neurology, Breast Unit, Deparment of Medical Oncology, Oscar Lambret Center, Lille, France and Neuro-oncology, University Hospital, Lille, France Full list of author information is available at the end of the article
}

The median survival of untreated patients with LM is 4-6 weeks. Breast cancers LM have the best prognosis, and median overall survival may reach 3 to 5 months with a combined treatment in recent studies [3-8]. The aim of treatment is to improve or stabilize neurological functions, maintain quality of life and prolong survival [1].

Prognostic factors have been identified: age, performance status, neurological status, LM characteristics, cerebrospinal fluid (CSF) block, LM related encephalopathy, extension of systemic disease and its treatment options, interval between diagnosis of primary tumour and LM

\section{C) Biomed Central}

(c) 2012 Le Rhun et al.; licensee BioMed Central Ltd. This is an Open Access article distributed under the terms of the Creative Commons Attribution License (http://creativecommons.org/licenses/by/2.0), which permits unrestricted use, distribution, and reproduction in any medium, provided the original work is properly cited. 
and type of primary tumour [1,9]. These factors remain heterogeneous among studies and are not very well validated. LM should be diagnosed in the early stages of the disease to prevent the progression of disabling neurological deficits. The diagnosis is assessed by CSF cytomorphological analysis or by concomitant typical CNS involvement symptoms and gadolinium enhanced magnetic resonance imaging (MRI) signs. CNS signs and symptoms, indicative of LM in more than $90 \%$ of patients, may be pleomorphic and are often subtle and difficult to distinguish from other cancer or antineoplastic treatment complications [10]. The specificity of gadolinium-enhanced MRI signs is up to $100 \%$ in solid tumors, balanced by a risk of false negative as high as $65 \%$ and false positive approaching 10\% [11]. Evidence of malignant cells in the CSF is diagnostic of LM. However, in patients ultimately positive for CSF cytology, up to $45 \%$ are cytologically negative on initial examination. The sensitivity reaches $80 \%$ with a second CSF analysis, but little benefit is obtained from more than two repeated lumbar punctures [1].
Insufficient CSF sampling, collecting CSF at distant site of symptoms and delayed processing have been reported to be sources of error [10-13]. Various biomarkers, such as tumour antigens, molecules involved in extravasation, migration or angiogenesis as well as chemokines [14-18] are under evaluation for their performance in detecting LM. Flow cytometry has been proposed as well as cytomics approaches, especially for CNS haematological involvement $[17,19]$.

CSF cytomorphology thus remains the gold standard for LM detection, but readout is only qualitative and not quantitative. Besides microscopic enumeration and morphological examination, cellular biomarkers appear promising.

The Veridex CellSearch ${ }^{\circledR}$ technology has been designed for the detection of circulating tumour cells (CTC) in blood from cancer patients and validated for the follow-up and prognosis of breast, prostate, colorectal, and lung cancer [20-22]. We adapted the technique and applied it to detect malignant cells in the CSF of 8 patients with breast cancer LM.

Table 1 Patients' characteristics at LM diagnosis

\begin{tabular}{|c|c|c|c|c|c|c|c|}
\hline $\begin{array}{l}\text { Number } \\
\text { of inclusion }\end{array}$ & $\begin{array}{l}\text { Age at } \mathrm{BC} \\
\text { diagnosis }\end{array}$ & BC characteristics & $\begin{array}{l}\text { Age at LM } \\
\text { diagnosis }\end{array}$ & Clinical symptoms & $\begin{array}{l}\text { Biochemical CSF } \\
\text { analysis }\end{array}$ & $\begin{array}{l}\text { Cytological CSF } \\
\text { analysis }\end{array}$ & Neuraxis MRI \\
\hline \multirow[t]{3}{*}{03} & \multirow[t]{3}{*}{56} & \multirow{3}{*}{$\begin{array}{l}\text { Undifferenciated } \\
\text { carcinoma, HPG 3, } \\
\text { ER-, PR -, HER2- }\end{array}$} & \multirow[t]{3}{*}{60} & \multirow[t]{3}{*}{ Cognitive disorders } & Proteinorachia: $0.24 \mathrm{~g} / \mathrm{l}$ & \multirow{3}{*}{$\begin{array}{l}\text { Presence of } \\
\text { malignant cells }\end{array}$} & LM involvement \\
\hline & & & & & Glycorachia: 2.7 & & Brain metastases \\
\hline & & & & & Chlorurorachia: 118 & & \\
\hline \multirow[t]{3}{*}{05} & \multirow[t]{3}{*}{61} & \multirow{3}{*}{$\begin{array}{l}\text { ILC, HPG 2, ER+, } \\
\text { PR+, HER2- }\end{array}$} & \multirow[t]{3}{*}{61} & \multirow[t]{3}{*}{ Dizziness } & Proteinorachia: $2.19 \mathrm{~g} / \mathrm{l}$ & \multirow{3}{*}{$\begin{array}{l}\text { Presence of } \\
\text { malignant cells }\end{array}$} & LM involvement \\
\hline & & & & & Glycorachia: 1.7 & & No brain metastases \\
\hline & & & & & Chlorurorachia: 124 & & \\
\hline \multirow[t]{3}{*}{06} & \multirow[t]{3}{*}{53} & \multirow{3}{*}{$\begin{array}{l}\text { Adenocarcinoma, } \\
\text { HPG 2, ER+, PR+, } \\
\text { HER2 - }\end{array}$} & \multirow[t]{3}{*}{74} & \multirow[t]{3}{*}{ None } & Proteinorachia: $0.48 \mathrm{~g} / \mathrm{l}$ & \multirow{3}{*}{$\begin{array}{l}\text { Presence of } \\
\text { malignant cells }\end{array}$} & LM involvement \\
\hline & & & & & Glycorachia: 3.5 & & No brain metastases \\
\hline & & & & & Chlorurorachia: 123 & & \\
\hline \multirow[t]{3}{*}{09} & \multirow[t]{3}{*}{42} & \multirow{3}{*}{$\begin{array}{l}\text { Adenocarcinoma, } \\
\text { HPG 2, ER+, PR +, } \\
\text { HER2 - }\end{array}$} & \multirow[t]{3}{*}{60} & \multirow[t]{3}{*}{ Dizziness, deafness } & Proteinorachia: $1.49 \mathrm{~g} / \mathrm{l}$ & \multirow{3}{*}{$\begin{array}{l}\text { Presence of } \\
\text { malignant cells }\end{array}$} & LM involvement \\
\hline & & & & & Glycorachia: 2.7 & & No brain metastases \\
\hline & & & & & Chlorurorachia: 116 & & \\
\hline \multirow[t]{3}{*}{10} & \multirow[t]{3}{*}{47} & \multirow{3}{*}{$\begin{array}{l}\text { IDC, HPG 2, ER+, } \\
\text { PR+, HER2- }\end{array}$} & \multirow[t]{3}{*}{59} & \multirow[t]{3}{*}{ Visual disorders } & Proteinorachia: $0.51 \mathrm{~g} / \mathrm{l}$ & \multirow{3}{*}{$\begin{array}{l}\text { Presence of } \\
\text { malignant cells }\end{array}$} & LM involvement \\
\hline & & & & & Glycorachia: 4.0 & & Brain metastases \\
\hline & & & & & Chlorurorachia: 120 & & \\
\hline \multirow[t]{3}{*}{11} & \multirow[t]{3}{*}{41} & \multirow{3}{*}{$\begin{array}{l}\text { ICL, HPG 3, ER+, } \\
\text { PR -, HER2 + }\end{array}$} & 45 & Cauda equine & Proteinorachia: $7.08 \mathrm{~g} / \mathrm{l}$ & Presence of & LM involvement \\
\hline & & & & & Glycorachia: 2 & & Brain metastases \\
\hline & & & & & Chlorurorachia: 113 & & \\
\hline 12 & 44 & IDC, HPG 2, ER+, & 57 & None & Proteinorachia: $0.28 \mathrm{~g} / \mathrm{l}$ & Presence of & LM involvement \\
\hline & & & & & Glycorachia: 4.9 & & Brain metastases \\
\hline & & & & & Chlorurorachia: 120 & & \\
\hline 13 & 45 & Undifferenciated & 50 & Cauda equina & Proteinorachia: $5.80 \mathrm{~g} / \mathrm{l}$ & Presence of & LM involvement \\
\hline & & $\begin{array}{l}\text { carcinoma, HPG 3, } \\
\text { ER+PR+ HFR2 - }\end{array}$ & & syndrome & Glycorachia: 3.6 & malignant cells & Brain metastases \\
\hline & & & & & Chlorurorachia: 111 & & \\
\hline
\end{tabular}

LM Leptomeningeal Metastases, CSF Cerebro Spinal Fluid, TC Tumor Cells, ILC Invasive Lobular Carcinoma, IDC Invasive Ductal Carcinoma, HPG histoprognostic grade, ER Estrogen Receptors, PR Progesterone Receptors, HER2 Human Epidermal Growth Factor Receptor-2, TTF1 Thyroid Transcription Factor 1, EGFR Epidermal Growth Factor Receptor, CNS Central Nervous System, MRI Magnetic Resonance Imaging, IT IntraThecal. 
Table 2 CSF characteristics at the time of the CellSearch ${ }^{\circledR}$ technology analysis

\begin{tabular}{|c|c|c|c|c|}
\hline $\begin{array}{l}\text { Inclusion number, } \\
\text { date of CSF sampling }\end{array}$ & $\begin{array}{l}\text { Treatment received for LM } \\
\text { at the time of CSF sampling } \\
\text { for CVT }\end{array}$ & Biochemical CSF analysis & $\begin{array}{l}\text { Cytomorphological CSF } \\
\text { analysis }\end{array}$ & $\begin{array}{l}\text { Enumeration of CSFTC } \\
\text { with the CellSearch } \\
\text { Veridex technology } \\
\end{array}$ \\
\hline \multirow[t]{3}{*}{$03-01$} & IV paclitaxel for 2 months then & Proteinorachia: 0.22 g/L & \multirow[t]{3}{*}{ No malignant cell (10 mL) } & \multirow[t]{3}{*}{0 CSFTC per mL } \\
\hline & carboplatin & Glycorachia: 3.5 mmol/L & & \\
\hline & No IT chemotherapy & Chlorurorachia: $121 \mathrm{~mol} / \mathrm{L}$ & & \\
\hline \multirow[t]{3}{*}{$05-01$} & IV paclitaxel since LM diagnosis & Proteinorachia: $1.13 \mathrm{~g} / \mathrm{L}$ & \multirow{3}{*}{$\begin{array}{l}\text { Presence of malignant cells } \\
(10 \mathrm{~mL})\end{array}$} & \multirow[t]{3}{*}{626 CSFTC per mL } \\
\hline & \multirow[t]{2}{*}{ No IT chemotherapy } & Glycorachia: 2.4 mmol/L & & \\
\hline & & $\overline{\text { Chlorurorachia: } 121 \mathrm{~mol} / \mathrm{L}}$ & & \\
\hline \multirow[t]{3}{*}{$05-02$} & IV paclitaxel since LM diagnosis & Proteinorachia: 1.42 g/L & \multirow{3}{*}{$\begin{array}{l}\text { Presence of malignant cells } \\
(10 \mathrm{~mL})\end{array}$} & \multirow[t]{3}{*}{1600 CSFTC per mL } \\
\hline & \multirow[t]{2}{*}{ No IT chemotherapy } & Glycorachia: 1.8 mmol/L & & \\
\hline & & Chlorurorachia: 117 mol/L & & \\
\hline \multirow[t]{3}{*}{$05-03$} & IV paclitaxel since LM diagnosis & Proteinorachia: $2.90 \mathrm{~g} / \mathrm{L}$ & \multirow[t]{3}{*}{ No malignant cell (10 mL) } & \multirow[t]{3}{*}{2100 CSFTC per mL } \\
\hline & \multirow[t]{2}{*}{ No IT chemotherapy } & Glycorachia: 0.3 mmol/L & & \\
\hline & & Chlorurorachia: 118 mol/L & & \\
\hline \multirow[t]{3}{*}{$06-01$} & \multirow[t]{3}{*}{ None } & Proteinorachia: 0.51 g/L & \multirow{3}{*}{$\begin{array}{l}\text { Presence of malignant cells } \\
(3 \mathrm{~mL})\end{array}$} & \multirow[t]{3}{*}{7 CSFTC per mL } \\
\hline & & Glycorachia: 3.7 mmol/L & & \\
\hline & & Chlorurorachia: $126 \mathrm{~mol} / \mathrm{L}$ & & \\
\hline \multirow[t]{3}{*}{$09-01$} & \multirow[t]{3}{*}{ None } & Proteinorachia: $1.90 \mathrm{~g} / \mathrm{L}$ & \multirow{3}{*}{$\begin{array}{l}\text { Presence of malignant cells } \\
(6 \mathrm{~mL})\end{array}$} & \multirow[t]{3}{*}{208 CSFTC per mL } \\
\hline & & Glycorachia: 3.3 mmol/L & & \\
\hline & & Chlorurorachia: $110 \mathrm{~mol} / \mathrm{L}$ & & \\
\hline \multirow[t]{3}{*}{$09-02$} & Oral vinorelbine & Proteinorachia: 1.64 g/L & \multirow[t]{3}{*}{ Not interpretable (10 mL) } & 130 CSFTC per mL \\
\hline & IT liposomal cytarabine (X1) & Glycorachia: 4.9 mmol/L & & \\
\hline & & Chlorurorachia: 108 mol/L & & \\
\hline $09-03$ & Oral navelbine & Proteinorachia: NA & Presence of malignant cells & 75 CSFTC per mL \\
\hline & IT liposomal cytarabine (X2) & Glycorachia: NA & & \\
\hline & & Chlorurorachia: NA & & \\
\hline $09-04$ & Oral navelbine & Proteinorachia: 1.88 g/L & Presence of malignant cells & 82 CSFTC per mL \\
\hline & IT liposomal cytarabine (X3) & Glycorachia: $4.5 \mathrm{mmol} / \mathrm{L}$ & $(10 \mathrm{~mL})$ & \\
\hline & & Chlorurorachia: $116 \mathrm{~mol} / \mathrm{L}$ & & \\
\hline $10-01$ & None & Proteinorachia: $0.80 \mathrm{~g} / \mathrm{L}$ & Presence of malignant cells & 0.2 CTC per mL \\
\hline & & Glycorachia: 3.4 mmol/L & $(5 \mathrm{~mL})$ & \\
\hline & & Chlorurorachia: $121 \mathrm{~mol} / \mathrm{L}$ & & \\
\hline $10-02$ & FEC 50 & Proteinorachia: 0.90 g/L & Presence of malignant cells & 0.4 CSFTC per mL \\
\hline & IT liposomal cytarabine $(X 1)$ & Glycorachia: 3.2 mmol/L & & \\
\hline & & Chlorurorachia: $120 \mathrm{~mol} / \mathrm{L}$ & & \\
\hline $11-01$ & None & Proteinorachia: 7.08 g/L & Presence of malignant cells & 478 CSFTC per mL \\
\hline & & Glycorachia: $2 \mathrm{mmol} / \mathrm{L}$ & & \\
\hline & & Chlorurorachia: $113 \mathrm{~mol} / \mathrm{L}$ & & \\
\hline $11-02$ & Capecitabine & Proteinorachia: 9.04 g/L & Presence of malignant cells & 940 CSFTC per mL \\
\hline & No IT chemotherapy & Glycorachia: $3.2 \mathrm{mmol} / \mathrm{L}$ & (8 mL) & \\
\hline & & Chlorurorachia: $100 \mathrm{~mol} / \mathrm{L}$ & & \\
\hline $12-01$ & None & Proteinorachia: $0.39 \mathrm{~g} / \mathrm{L}$ & Presence of malignant cells & 5 CSFTC per mL \\
\hline & & Glycorachia: 5.4 mmol/L & & \\
\hline & & Chlorurorachia: $119 \mathrm{~mol} / \mathrm{L}$ & & \\
\hline
\end{tabular}


Table 2 CSF characteristics at the time of the CellSearch ${ }^{\circledR}$ technology analysis (Continued)

\begin{tabular}{|c|c|c|c|c|}
\hline \multirow[t]{3}{*}{$12-02$} & Oral capecitabine + lapatinib & Proteinorachia: $0.21 \mathrm{~g} / \mathrm{L}$ & \multirow[t]{3}{*}{ No malignant cells (8 mL) } & \multirow[t]{3}{*}{0 CSFTC per mL } \\
\hline & \multirow[t]{2}{*}{ IT liposomal cytarabine (X1) } & Glycorachia: 5.4 mmol/L & & \\
\hline & & Chlorurorachia: 119 mol/L & & \\
\hline \multirow[t]{3}{*}{$13-01$} & \multirow[t]{3}{*}{ None } & Proteinorachia: $8.84 \mathrm{~g} / \mathrm{L}$ & \multirow{3}{*}{$\begin{array}{l}\text { Presence of malignant cells } \\
(7 \mathrm{~mL})\end{array}$} & \multirow[t]{3}{*}{1560 CSFTC per mL } \\
\hline & & Glycorachia: 2.4 mmol/L & & \\
\hline & & Chlorurorachia: 106 mol/L & & \\
\hline
\end{tabular}

LM Leptomeningeal Metastasis, CSF CerebroSpinal Fluid, CSFTC CSF Tumor Cells, IT IntraThecal, IV IntraVenous, FEC Fluorouracil Epirubicin Cyclophosphamide, CVT CellSearch ${ }^{\circledR}$ Veridex Technology, NA Not Available.

\section{Methods}

All the patients were included into a randomized phase 3 study evaluating the role of the intrathecal treatment in LM from breast cancer (DEPOSEIN, EudraCT $\mathrm{N}^{\circ}$ : 2010-023134-23) after approbation of the appropriate regional ethic committee ("Comité de Protection des Personnes - CPP Nord Ouest III) on May 3rd 2011 and in compliance with the Helsinki Declaration. All patients had given their written informed consent for the translational study. DEPOSEIN is a multicentric randomized phase III study designed to assess the role of intra-CSF liposomal cytarabine in the treatment of LM. Patients are randomized in 2 arms: liposomal cytarabine intraCSF and concomitant systemic treatment versus systemic treatment alone. LM diagnosis was established in 8 patients with primary breast cancer, according to usual diagnostic criteria. The CellSearch ${ }^{\circledR}$ technology defines CTCs after immunomagnetic enrichment of cells expressing EpCAM, using nuclear staining with 4, 6-diamidino2- phenylindole (DAPI), and immunofluorescence detection of cytokeratin and CD45 [22]. Five mL of CSF samples were collected on CellSave ${ }^{\circledR}$ Preservative Tubes (Veridex, Raritan, NJ) and analyzed within 3 days after CSF sampling using the standard CellSearch ${ }^{\circledR}$ protocol and the CTC Epithelial Cell Kit (Veridex, Raritan, NJ). The methodology is designed to initially eliminate, in centrifuged blood samples, the plasma above the buffy coat and erythrocytes by optically detecting the level of the latter. In order to avoid undue alarms, after deposition of $5 \mathrm{~mL}$ of CSF in the conic tube of the "circulating tumor cell kit"; the outside of the tube was simply darkened with a black felt-tip up to the fluid level to mimick the erythrocytes level. Five $\mathrm{mL}$ of dilution buffer were then added and the mixture homogeneized and centrifuged. The "lured-tube" was then placed into the preparation station and submitted to automate preparation as for blood samples.

Briefly, the latter resulted in an enriched sample where cells were optically aligned along the upper panel of a glass chamber, maintained by strong magnets, allowing for automated fluorescence microscopy and cell images digitalization, a cell being defined as both nuclear DAPI and cell-surface staining. This allowed the observation of EpCAM+/cytokeratin + cells with a DAPI-stained nucleus and no CD45 staining, magnetically maintained in a single plane for electronic image analysis and digitalization. The automated fluorescence microscope proposes galleries of cells, which were validated upon visual image review. DAPI+/CD45+/EpCAM-/cytokeratincells were counted as leukocytes.

In parallel, cytocentrifuge smears of each CSF sample were prepared within one hour after CSF sampling and stained (May Grunwald Giemsa) for visual cytomorphological examination of tumor cells, and standard CSF biochemical composition was analyzed.

\section{Results}

The characteristics of the patients at the time of LM diagnosis are described in Table 1. Five patients had concomitant parenchymal brain metastasis. At LM diagnosis, 6 patients presented with symptoms and signs, mostly including cauda equina syndrome and dizziness. Proteinorachia varied from 0.24 to $7.08 \mathrm{~g} / \mathrm{L}$. CSF samples volumes varied between 5 and $10 \mathrm{~mL}$ for usual cytomorphological analysis, tumor cells were detected but not enumerated in all the patients and MRI showed evidence of LM signs in 8 patients.

The first part of the translational study was to adapt the CellSearch ${ }^{\circledR}$ technology for the detection and enumeration of tumor cells in the CSF of breast cancer LM. Sixteen CSF samples were available for the evaluation of the innovative method: These samples are described in Table 2. All CSF samples were obtained at lumbar site and analysed at LM diagnosis or at different times during LM treatment. Malignant cells were observed at cytomorphological analysis in 12 samples, and in 14 samples with the CellSearch ${ }^{\circledR}$ technology, with tumor cells numbers ranging between 1 and $10500 / 5 \mathrm{~mL}$. Figure 1 shows representative epithelial tumour cells detected in CSF from one breast cancer patient by CellSearch $^{\circledR}$ technology. These cells have similar aspects to epithelial tumour cells described in blood as CTC from breast cancer patients [17]. Figure 2 summarizes quantitative results of tumor cells in CSF by CellSearch $^{\circledR}$ technology. 


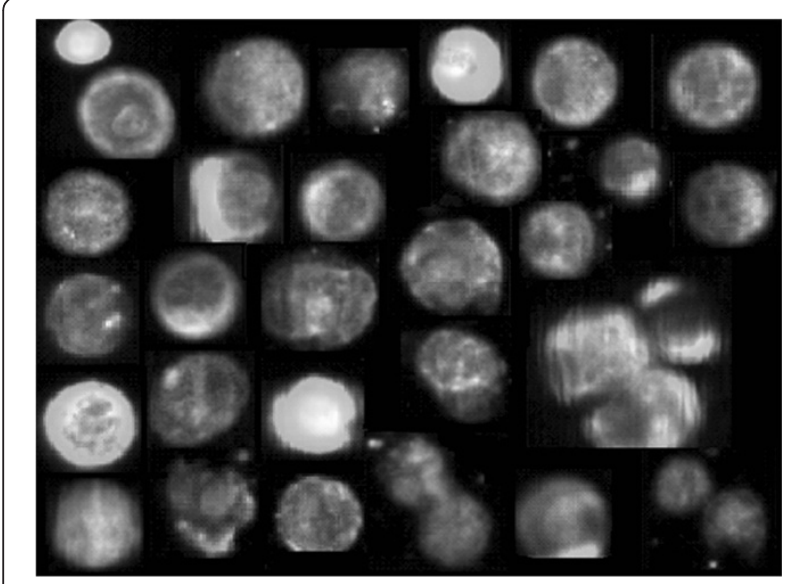

Figure 1 Collection of validated images of tumor cells (EpCAM+/ cytokeratin + cells with a DAPI-stained nucleus and no CD45 staining) detected in the CSF from a patient with LM secondary to breast cancer.

Usual cytological CSF analysis was not interpretable in one sample from patient 09 because of deterioration of the cells, despite an usual procedure of sampling and processing of the CSF, while CellSearch ${ }^{\circledR}$ showed 650 tumor cells in $5 \mathrm{~mL}$. In another patient, the usual cytologic analysis did not detect any tumor cell but CellSearch ${ }^{\circledR}$ technology enumerated more than 2000 cells $/ \mathrm{mL}$.

Three patients were studied once with both techniques, with concordant positive and negative results. Two patients were studied twice, one with low levels of cells ( 1 and 2 cells $/ 5 \mathrm{~mL}$ ) and the other with elevated numbers (2392 and 4700 cells $/ 5 \mathrm{~mL}$ ). One patient was analyzed three times with numbers increasing from 3129 to 10500 cells $/ 5 \mathrm{~mL}$. Another patient was studied four times, with numbers of tumor cells decreasing from 1042 cells to 408 cells $/ 5 \mathrm{~mL}$ ).

\section{Discussion}

In cancer patients, the diagnosis of LM remains a major problem. CNS signs and symptoms orienting towards a diagnosis of LM are often subtle. Diagnosis assessment implies the use of specific techniques, which are not applied in the usual follow-up of solid tumour patients, namely gadolinium enhanced MRI and CSF cytomorphological analyses. Yet, even the latter may be not contributive, as many patients are both radiographically and cytomorphologically negative even in the presence of evocative symptoms.

Different biomarkers have been tested in order to increase the sensitivity of CSF analyses but their use is hampered by a poor specificity/sensitivity, a lack of standardization of CSF sampling and processing, and the absence of agreement on cut-off levels. Because of all these limitations, CSF cytomorphology remains the gold standard for CSF analysis.

The CellSearch ${ }^{\circledR}$ method provides a semi-automated cell analysis, based on the assessment of nuclear and surface markers, which vastly improves the sensitivity, reliability, objectivity, and accuracy of circulating tumor cells detection in the blood compared to cytomorphology [20-22]. In recent studies [23,24], CellSearch ${ }^{\circledR}$ technology, applied by spiking blood with CSF [24], was shown to be of interest for the early detection of CSF malignant cells. We present here a simple modification of this technology allowing for a precise direct quantification of CTC in only $5 \mathrm{~mL}$ of CSF. Moreover, the use of CellSave ${ }^{\circledR}$ Preservative tubes for collection authorized

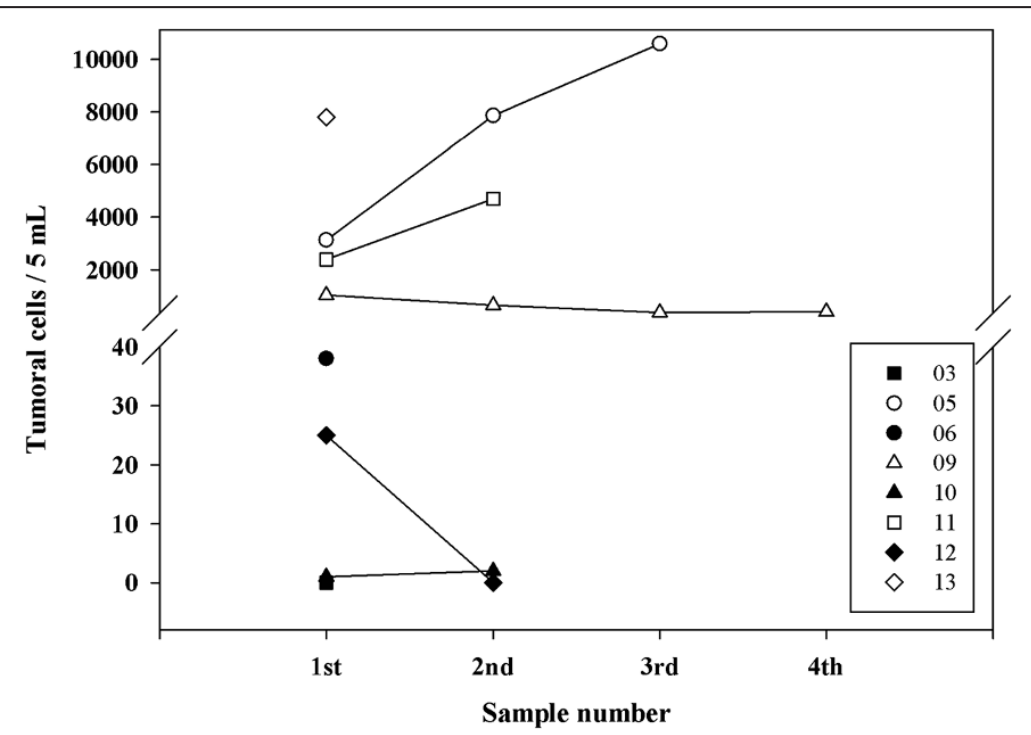

Figure 2 Individual numbers of tumor cells in CSF detected using the CellSearch ${ }^{\circledR}$ technology from the 8 patients included in the study (identified by their number of inclusion at the right box). 
a 3-days delay in sample processing, which can be interesting for centralized analyses. The specificity of this technique, besides the use of tumor-associated markers, is enhanced by visual appreciation of the digitalized cells. Indeed, no cells with a tumor-like morphology or phenotype were detected in the CSF of a small series of control patients without LM (data not shown). The presence of an additional free channel for other reagents also makes possible to analyse the cell's HER2-Neu or EGFR immunofluorescence or to investigate for any other relevant marker allowing the exploration of these neurological metastatic cells.

Furthermore, sequential studies in our short series appear very concordant with either low or elevated levels of cells, which is very encouraging for the evaluation of therapies.

\section{Conclusions}

We report in this pilot study an easy new method for the identification and the quantification of malignant cells in the cerebrospinal fluid. These results, which need to be confirmed in a larger series, suggests that CellSearch ${ }^{\circledR}$ technology could be of interest during cancer patients' follow-up, for initial characterization of LM and notably to evaluate the efficacy of chemotherapy in its management. According to these first results, the CellSearch $^{\circledR}$ technology will continue to be evaluated during the clinical randomized study DEPOSEIN.

\section{Competing interests}

The authors do not have any potential financial competing interests to declare.

\section{Authors' contribution}

All authors listed have contributed significantly to the experiment or the writing on the manuscript. ELR conceived the study, participated in its design and coordination, helped to draft the manuscript. FM carried out the cellular immunoassay and acquired data. TQ carried out the cellular immunoassay and acquired data. JB participated in the design of the study and approved the manuscript. MDCB participated in the design of the study and helped to draft the manuscript. GCF designed the study, analysed and interpreted data, helped to draft, revised and approved the manuscript. All authors read and approved the final manuscript.

\section{Acknowledgements \\ "Nancytomique" platform has been supported by CPER-Région Lorraine, FEDER, and Ligue contre le Cancer and this project by Région Lorraine (CERONC) and Recherche Clinique of CHU Nancy. \\ Authors would like to acknowledge Arthur Lefèvre and Martine Roussel for their implication in this study and Marie Christine Béné for reading and improving the drafts of the manuscript and her support in the "rare events" clinical research projects.}

\section{Deposein}

Study is promoted by Oscar Lambret Center. Research funding was supported by Mundipharma.

\section{Author details}

${ }^{1}$ Neurology, Breast Unit, Deparment of Medical Oncology, Oscar Lambret Center, Lille, France and Neuro-oncology, University Hospital, Lille, France. ${ }^{2} \mathrm{CHU}$ Nancy, Nancytomique, Laboratoire d'Immunologie, Pôle Laboratoires, Vandoeuvre lès Nancy, Nancy, France. ${ }^{3} \mathrm{CHU}$ Nancy, Nancytomique,
Laboratoire d'Immunologie, Pôle Laboratoires, Vandoeuvre lès Nancy, Nancy, France. ${ }^{4}$ Breast Unit, Department of Medical Oncology, Centre Oscar Lambret, Lille, France and University of Lille Nord de France, Lille, France. ${ }^{5} \mathrm{CHU}$ Nancy, Nancytomique, Laboratoire d'Immunologie, Pôle Laboratoires, Vandoeuvre lès Nancy, France and Université Henri Poincaré, Faculté de Médecine, Vandoeuvre lès Nancy, EA4369 RHEM, Nancy, France. ${ }^{6} \mathrm{CHU}$ Nancy, Nancytomique, Laboratoire d'Immunologie, Pôle Laboratoires, Vandoeuvre lès Nancy, France and Université Henri Poincaré, Faculté de Médecine, Vandoeuvre lès Nancy, EA4369 RHEM, Nancy, France.

Received: 9 July 2012 Accepted: 2 November 2012

Published: 12 November 2012

References

1. Chamberlain MC: Leptomeningeal metastasis. Curr Opin Oncol 2010, 22:627-635

2. Groves MD: New strategies in the management of leptomeningeal metastases. Arch Neurol 2010, 67:305-312.

3. Rudnicka H, Niwinska A, Murawska M: Breast cancer leptomeningeal metastasis - the role of multimodality treatment. J Neurooncol 2007 84:57-62.

4. Clatot F, Philippin-Lauridant G, Ouvrier MJ, Nakry T, Laberge-Le-Couteulx S, Guillemet C, Veyret C, Blot E: Clinical improvement and survival in breast cancer leptomeningeal metastasis correlate with the cytologic response to intrathecal chemotherapy. J Neurooncol 2009, 95(3):421-426.

5. Gauthier H, Guilhaume MN, Bidard FC, Pierga JY, Girre V, Cottu PH, Laurence $V$, Livartowski A, Mignot L, Diéras V: Survival of breast cancer patients with meningeal carcinomatosis. Ann Oncol 2010, 21(11):2183-2187.

6. de Azevedo CR, Cruz MR, Chinen LT, Peres SV, Peterlevitz MA, de Azevedo Pereira AE, Fanelli MF, Gimenes DL: Meningeal carcinomatosis in breast cancer: prognostic factors and outcomes. J Neurooncol 2011, 104(2):565-572.

7. Lee S, Ahn HK, Park YH, Nam Do H, Lee Jl, Park W, Choi DH, Huh SJ, Park KT, Ahn JS, Im YH: Leptomeningeal metastases from breast cancer: intrinsic subtypes may affect unique clinical manifestations. Breast Cancer Res Treat 2011, 129(3):809-817.

8. Zairi F, Kotecki N, Rodrigues I, Baranzelli MC, Andre C, Dubois F, Devos P, Faivre-Pierret M, Assaker R, Bonneterre J, Le Rhun E: Prospective follow-up of a cohort of 112 patients with leptomeningeal metastases of breast cancer recruited from 2007 to 2011: prognostics factors. J Clin Oncol 2012, General Poster Session, Central Nervous System, abstract 2070, American Society of Clinical Oncology, Annual Meeting, 2012; June, Chicago, IL. should be changed in General Poster Session, Central Nervous System Tumors, abstract 2070, American Society of Clinical Oncology, Annual Meeting, 2012; June Chicago, IL. Citation: J Clin Oncol 30, 2012 (suppl; abstr 2070).

9. Oechsle K, Lange-Brock V, Kruell A, Bokemeyer C, de Wit M: Prognostic factors and treatment options in patients with leptomeningeal metastases of different primary tumors: a retrospective analysis. J Cancer Res Clin Oncol 2010, 136:1729-1735.

10. Chamberlain MC, Glantz M, Groves MD, Wilson WH: Diagnostic tools for neoplastic meningitis: detecting disease, identifying patient risk, and determining benefit of treatment. Semin Oncol 2009, 36:S35-S45.

11. Chamberlain MC: Leptomeningeal metastases in the MRI era. Neurology 2011, 76:200-201.

12. Dux R, Kindler-Röhrborn A, Annas M, Faustmann P, Lennartz K, Zimmermann CW: A standardized protocol for flow cytometric analysis of cells isolated from cerebrospinal fluid. J Neurol Sci 1994, 121:74-78.

13. Glantz MJ, Cole BF, Glantz LK, et al: Cerebrospinal fluid cytology in patients with cancer: minimizing false-negative results. Cancer 1998 82:733-739.

14. Corsini E, Bernardi G, Gaviani P, Silvani A, de Grazia U, Ciusani E, Croci D, Salmaggi A: Intrathecal synthesis of tumor markers is a highly sensitive test in the diagnosis of leptomeningeal metastasis from solid cancers. Clin Chem Lab Med 2009, 47:874-879.

15. Groves M, Hess KR, Puduvalli VK, Colman H, Conrad CA, Gilbert MR, Weinberg J, Cristofanilli M, Yung WK, Liu TJ: Biomarkers of disease: cerebrospinal fluid vascular endothelial growth factor (VEGF) and stromal cell derived factor (SDF)-1 levels in patients with neoplastic 
meningitis (NM) due to breast cancer, lung cancer and melanoma. J Neurooncol 2009, 94:229-234.

16. Römpp A, Dekker L, Taban I, Jenster G, Boogerd W, Bonfrer H, Spengler B, Heeren R, Smitt PS, Luider TM: Identification of leptomeningeal metastasis-related proteins in cerebro-spinal fluid of patients with breast cancer by a combination of MALDI-TOF, MALDI-FTICR and nanoLC-FTICR MS. Proteomics 2007, 7:474-481.

17. Weston CL, Glantz MJ, Connor JR: Detection of cancer cells in the cerebrospinal fluid: current methods and future directions. Fluids Barriers CNS 2011, 8:14.

18. Walbert T, Groves MD: Known and emerging biomarkers of leptomeningeal metastasis and its response to treatment. Future Oncol 2010, 6:287-297.

19. Tárnok A, Bocsi J, Brockhoff G: Cytomics - importance of multimodal analysis of cell function and proliferation in oncology. Cell Prolif 2006, 39:495-505

20. Miller MC, Doyle GV, Terstappen LW: Significance of Circulating Tumor Cells Detected by the Cell Search System in Patients with Metastatic Breast Colorectal and Prostate Cancer. J Oncol 2010, 2010:617421.

21. Riethdorf S, Fritsche H, Müller V, Rau T, Schindlbeck C, Rack B, Janni W, Coith C, Beck K, Jänicke F, Jackson S, Gornet T, Cristofanilli M: Detection of circulating tumor cells in peripheral blood of patients with metastatic breast cancer: a validation study of the CellSearch system. Clin Cancer Res 2007, 13:920-928.

22. Allard WJ, Matera J, Miller MC, Repollet M, Connelly MC, Rao C, Tibe AG, Uhr JW, Terstappen LW: Tumor cells circulate in the peripheral blood of all major carcinomas but not in healthy subjects or patients with nonmalignant disease. Cin Cancer Res 2004, 10(20):6897-6904.

23. Nayak L, Fleisher M, Gonzalez-Espinoza R, Reiner AS, Panageas K, Lin O, Liu C, DeAngelis LM, Omuro AM: Immunomagnetic platform technology (IMPT) for the diagnosis of leptomeningeal metastasis in solid tumors (LMST). ASCO Poster Dis Sess 2010, Abstract Number: 2032. should be changed in Poster Discussion Session, Central Nervous System Tumors, abstract 2032, American Society of Clinical Oncology, Annual Meeting, 2010; June, Chicago, IL. Citation: J Clin Oncol 28:15s, 2010 (suppl; abstr 2032).

24. Patel AS, Allen JE, Dicker DT, Peters KL, Sheehan JM, Glantz MJ, El-Deiry WS: Identification and enumeration of circulating tumor cells in the cerebrospinal fluid of breast cancer patients with central nervous system metastases. Oncotarget 2011, 2:752-760.

doi:10.1186/1472-6890-12-21

Cite this article as: Le Rhun et al:: Development of a new method for identification and quantification in cerebrospinal fluid of malignant cells from breast carcinoma leptomeningeal metastasis. BMC Clinical Pathology 2012 12:21

\section{Submit your next manuscript to BioMed Central and take full advantage of:}

- Convenient online submission

- Thorough peer review

- No space constraints or color figure charges

- Immediate publication on acceptance

- Inclusion in PubMed, CAS, Scopus and Google Scholar

- Research which is freely available for redistribution 